\section{Forfattere og redaktører}

Mogens Fønss, f. 1918, ved Gyldendal 1942-46, kulturmedarbejder ved Information 1948-55, ved Gutenberghusbladene 1955-80, bl.a. chefred. af Hjemmet 1970-75, gastronomisk-kulturhistoriske bidrag i Mad og Gæster og Politiken.

Christian Glenstrup, f. 1929, lærereksamen 1951, mag. art. (pædagogik) 1974. Undervisning i folkeskolen, på seminarier, Københavns Universitet og Danmarks Lærerhøjskole. 1967-1993 forskningsbibliotekar ved Danmarks pædagogiske Bibliotek.

Michael Harbsmeier, f. 1951, mag. art. (antropologi) 1976, forskningsstipendiat ved Det humanistiske Forskningscenter, Københavns Universitet 1986-90, senest gæsteforsker ved Center for europæisk litteratur, Universitetet i Bergen. Talrige artikler om rejsebeskrivelser og antropologiens (for)historie.

JeSPer Düring JørGensen, f. 1944, cand. phil. (dansk) 1972, forskningbibliotekar ved Det kongelige Bibliotek 1972, og senere tillige sikringschef, sst. Har bl.a. skrevet om tysk kulturpropaganda i Danmark, medarbejder ved Dansk Biografisk Leksikon 3. udg.

Christian KaAtmanN, f. 1948, cand.mag. (historie og tysk) 1983, fuldmægtig ved Det kongelige Bibliotek. Ansat af Statens humanistisk Forskningsråd 1984-86, ved Institut for Grænseforskning 1986-87. Har bl.a. skrevet om europæisk middelalder og sønderjysk lokalhistorie.

JoHN T. LAURIDSEN, f. 1951, mag. art. (historie) 1980, dr. phil. 1988, forskningsbibliotekar 1988 og fra 1993 forskningsleder ved Det kongelige Bibliotek. Har skrevet en række afhandlinger med emner fra dansk og international historie.
HAKON Lund, f. 1928, mag. art. (kunsthistorie) 1959, forskningsbibliotekar ved Kunstakademiets Bibliotek 1960 og overbibliotekar sst. fra 1977. Har skrevet og redigeret afhandlinger og værker, primært om dansk arkitekturhistorie.

Gert Posselt, f. 1955, cand. mag. (historie og etnologi). Fagredaktør ved Danmarks Nationalleksikon. Diverse artikler, bl.a. om Poul Helgesens læsning af Luther.

VibeKe Stybe, f. 1922, bibliotekar og børnelitteraturhistoriker, til 1990 leder af Afdelingen for Børnelitteratur på Danmarks pædagogiske Bibliotek. Har skrevet en lang række bøger og artikler om børnelitteratur.

Bodil Marie ThOMSEN, f. 1956, cand. phil. (dansk), tilknyttet Center for Kulturforskning, Århus Universitet, medarbejder ved Danmarks Nationalleksikon (om mode). Har skrevet en række artikler om mode, film og andre visuelle udtryk.

Michael Wagner, f. 1956, cand. phil. (historie) 1986, kandidatstipendiat, Historisk Institut, Århus Universitet, Har publiceret en række artikler om teknologihistoriske emner og teknologi/samfundsproblematikken.

ANN R. Welling, f. 1943, cand. mag. (historie og kunsthistorie) 1972, forskningsbibliotekar ved Roskilde Universitetsbibliotek 1972-77 og siden ved Det kongelige Bibliotek. Konsulent ved Danmarks Nationalleksikon. Har bl.a. udgivet Dansk historisk Bibliografi 19741976, 1986, og 1970-1973, 1-2, 1993 (begge sammen med Erland Kolding Nielsen). 